\title{
PLANTING DATE IN RELATION TO INSECT AND ANIMAL PESTS ATTACKING CUCUMBER PLANTS UNDER PROTECTED CULTIVATION AT GIZA GOVERNORATE
}

\author{
SHALABY, F.F. ${ }^{1}$, F.A. ALI ${ }^{2}$, A.A. HAFEZ ${ }^{1}$ and HAYAM M. SAAD ${ }^{2}$ \\ 1. Plant Protection Dept., Faculty of Agriculture, Benha University \\ 2. Plant Protection Research Institute, ARC, Dokki, Giza
}

(Manuscript received 4 April 2013)

\begin{abstract}
Cucumber plants were cultivated in greenhouses in autumn and spring seasons, while autumn is the main season to provide markets with cucumber fruits in cold weather. The main pests of this season are Bemisia tabaci (Genn.), Aphis gossypii Glover and Tetranychus urticae (Koch) under plastic greenhouses were studied during two successive autumn season in (2008-2009) and (2009-2010) at El-Dokki location, Giza governorate. Cucumber plants in the early planting date were attacked by the highest population of B. tabaci while the highest populations of $A$. gossypii, and $T$. urticae were recorded in late planting date. This study also evaluated the potency of some control approaches to face the severe infestation of T.urticae on cucumber plants under greenhouse during summer season by using eight acaricides. The obtained results showed that the reduction percentages of T.urticae mobile individuals, 24 hours after treatments ranged between $96 \%$ by Agromec and $57.6 \%$ by Bio-fly, while after 7 days, all the tested acaricides were very effective against $T$. urticae. It was concluded that using any of the tested acaricides could be considered selectivity and safety.
\end{abstract}

\section{INTRODUCTION}

Cucumber crop (Cucumis sativus L.) is one of the most important vegetable crops planted under greenhouses and open fields in Egypt. Cucumber plants cultivated in greenhouses in autumn and spring seasons were attacked by many harmful and destructive sap sucking insect and animal pests, which cause qualitative and quantitative reduction in yield (El-Khayat et al., 2010). From these pests, whitefly, Bemisia tabaci (Genn.), aphid, Aphis gossypii Glover and the two spotted spider mite, Tetranychus urticae (Koch) which feed on the plant sap through cucumber leaves causing serious damage according to rates of infestation and the most abundant species on leaves of plants under greenhouse (Baiomy, 2008). Whitefly and aphids, also, excrete honey dew which hamper photosynthesis and fruits become unmarketable, and they are serious vectors for transmission of plant viruses (Mohamed, 2011). The two spotted mite, $\mathrm{n}$ T.urticae causes also a lot of damage 
leading to reduction in plant growth (Abdel-Wahed, 2003). Due to the seriousness of these pests, many growers become obligated for the excessive use of insecticides and/or acaricides which leads to environmental problems such as reduction of beneficial biocontrolling insects and increasing pesticidal pollution. For this reason, the present investigation was carried out to find out the relationship between the planting date of cucumber plants and the rate of infestation by these pests hoping to select the date in which the pests infestation is the lowest. Accordingly this method may be fairly considered as a new approach towards controlling these pests under greenhouse conditions.

\section{MATERIALS AND METHODS}

This investigation was carried out at El-Dokki protected cultivation center, Giza governorate during two years (2008/2009 and 2009/2010).

The main objective of this investigation to study the effect of three planting dates on the level infestation of cucumber plants with major insect and animal pests, B. tabaci, A. gossypii and T. urticae in greenhouses. Four greenhouses were specified for this experiment, three cucumber greenhouses for the three planting dates in the autumn season, while the fourth was planted for control the two spotted spider mite with acaricides. The area for each greenhouse of the three planting dates was $540 \mathrm{~m}^{2}$ with $60 \mathrm{~m}$ long and $9 \mathrm{~m}$ wide and $3.25 \mathrm{~m}$ height covered with plastic (Ali, 1993). Each greenhouse contained five rows, each of $1 \mathrm{~m}$ wide and $60 \mathrm{~m}$ long, and the distance between two seedlings in the row was $50 \mathrm{~cm}$.

Samples of 25 leaves for each were picked weekly at random from cucumber plants (5 leaves from each row) representing the three plant levels (upper, middle and lower) from each greenhouse.

Three greenhouses were cultivated with cucumber variety (Dp 162) in three different planting dates in autumn season as follow:

A- Early planting date (mid-September)

B- Common planting date (end September)

C- Late planting date (mid-October)

During two successive autumn seasons in (2008/09 and 2009/10).

Leaves of each sample were placed in plastic bags and transported to the laboratory where those were thoroughly inspected. Inspection of the first sample took place after two weeks of seedlings' cultivation . 


\section{Efficiency of untraditional acaricides against the two spotted spider mite $T$. urticae infesting cucumber plants under green house:}

This experiment was carried out to evaluate some untraditional bio-acaricides to be compared with chemical acaricides against two-spotted spider mite on cucumber plants under protected cultivation in spring season (2012) because the population of the tested pest indicated that the spider mite gave high numbers and cause severe damage on cucumber plants in spring season (Saad, 2002).

Ten treatments were tested in this experiment under multispan greenhouse (four spans) included 20 rows of cucumber plants cultivated on the two sides of each row provided with drip irrigation systems.

The greenhouse was cultivated with seedlings of cucumber (hybrid, 466), which were planted on February, 25 $5^{\text {th }} 2012$ in spring season. Treatments and replicates (3/treatment) were arranged in a complete randomized blocks, while the control treatment was selected without spray. Spraying was applied on June, $20^{\text {th }}$, 2012 by using a knapsack motor sprayer with 10 liters tank for each plot. Cucumber plants of a row received the acaricides spray of a treatment, while the neighbouring row was left without spraying as a barrier to prevent acaricides drift that may interfere with the other treatments.

Samples of leaves (15 leaves/treatment) were, randomly, picked as 5 leaves/plot just before spraying and $1,3,5,7,10,12$ and 15 days after spraying. Leaves of each sample were placed in a plastic bag and transport to the laboratory where each leaf was, thoroughly examined from both surfaces under a binocular sterio-microscope. Mobile individuals of Tetranychus urticae stages were counted (larvae, nymphs and adults) and recorded.

Recommendations of the chosen acaricides were dependent upon:

a- $80 \%$ reduction by chemical acaricides and $\mathbf{b}-70 \%$ reduction by bio - acaricides. 
List of the acaricides assayed for their efficacy against $T$. urticae infesting cucumber plants under greenhouse at Giza governorate, and rates of application.

\begin{tabular}{|l|c|c|c|}
\hline \multicolumn{1}{|c|}{ Trade name } & Common name & $\begin{array}{c}\text { Type of } \\
\text { compound }\end{array}$ & $\begin{array}{c}\text { Rate / } 100 \mathrm{~L} . \\
\text { water }\end{array}$ \\
\hline 1- Acari-stop 50\%SC & Clofentazine & Chemical & $40 \mathrm{CC}$ \\
\hline 2- Milbeknock 1\% EC & Milbemectin & Biological & $50 \mathrm{CC}$ \\
\hline 3- Prev. AM 6\% SL & Orange oil & Plant extract & $400 \mathrm{CC}$ \\
\hline 4- Bio- larve 5\% EC & Emamectin benzeate & Biological & $30 \mathrm{CC}$ \\
\hline 5- Bio-fly $\left(3 \times 10^{6}\right.$ units) & Beauvaria bassiana & Biological & $50 \mathrm{CC}$ \\
\hline 6- Agromec $1.8 \% \mathrm{EC}$ & Abamectin & Biological & $50 \mathrm{CC}$ \\
\hline 7- Bio- larve 5\% EC & Emamectin benzoate & Biological & $15 \mathrm{CC}$ \\
\hline 8- Pyricide $24 \% \mathrm{EC}$ & Chlorfenapyr & Chemical & $75 \mathrm{CC}$ \\
\hline 9- Citroguard 15\% EC & Pyridaben & Chemical & $200 \mathrm{CC}$ \\
\hline
\end{tabular}

The percentages of reduction for the population after spraying were calculated according to the equation of Henderson and Tiltons (1955).

\section{RESULTS AND DISCUSSION}

\section{Population fluctuation of:}

\section{Bemisia tabaci (Genn.) adults in the greenhouse:}

Data presented in Table (1)show the adult numbers of B.tabaci counted on leaves of autumn cucumber plants during three planting dates under plastic greenhouses .Regarding the total population of adults counted throughout the whole season, those were, slightly, higher on the three planting dates of 2008/2009 year (1025, 729 and 530 adults, respectively) than those counted throughout 2009/2010 (964, 663 and 499 adults). Also, plants of the earliest planting date (September, $15^{\text {th }}$ ) harboured the highest total count of B. tabaci adults (1025 and 964 in 2008/09 and $2009 / 10$, respectively). Seasonal count of the common planting date (Sept., 30 ${ }^{\text {th }}$ ) came the next (729 and 663 adults), while, plants of the late autumn planting date (October, $15^{\text {th }}$ ) manifested the lowest seasonal number of adults in the two years, being 530 and 499 adults, respectively (Table, 1).

Concerning the population of adults which were counted during the successive weeks, it is clear from Table (1) that adults population started with low number ( 9,2 and 1 adult/25 cucumber leaves of the three planting dates, respectively in year 2008/09, opposed to 5, 2 and 1 adult, respectively in year (2009/10). With all 
planting dates of the two years, these numbers increased successively during the successive weeks until reach the first (highest) peak of population abundance showing 205 adults on November, $13^{\text {th }}, 128$ on November, $20^{\text {th }}$ and 102 adults on December, $4^{\text {th }} 2008$, opposed to 190 and 116 adults on November, $27^{\text {th }}$ for the early, common and late palnting dates of the subsequent year (2009), respectively. After this peak, the population abundance decreased for 1-3 weeks, then reincreased again to from the second peak of abundance showing 110 adults/25 leaves on December, $4^{\text {th }}, 77$ adults on December, $18^{\text {th }}$ and 75 adults on December, $25^{\text {th }} 2008$ opposed to 70 and 71 adults on December, $18^{\text {th }}$ and 81 adults on December, $11^{\text {th }} 2009$ for plants of the early, common and late planting dates, respectively (Table, 1 ). After the second peak, the population density of whitefly adults decreased successively towards the end of the season.

Statistical analysis between seasonal total numbers of $B$. tabaci adults in the three planting dates revealed significant differences in the two years of the study (Calculated LSD' s were 33.06 and 23.23, respectively (Table, 1).

Table 1. Bemisia tabaci adult counts/ 25 leaves of autumn cucumber plants of three planting dates during two successive years.

\begin{tabular}{|c|c|c|c|c|c|c|}
\hline \multirow{2}{*}{$\begin{array}{c}\text { Date of } \\
\text { Inspections }\end{array}$} & \multicolumn{5}{|c|}{ No. of B. tabaciadults / 25 leavess } \\
\cline { 2 - 7 } & $\begin{array}{c}\text { Early } \\
\text { Sept., } 15\end{array}$ & $\begin{array}{c}\text { common } \\
\text { Sept, 30 }\end{array}$ & $\begin{array}{c}\text { Late } \\
\text { Oct., } 15\end{array}$ & $\begin{array}{c}\text { Early } \\
\text { Sept., 15 }\end{array}$ & $\begin{array}{c}\text { common-2010 } \\
\text { Sept, 30 }\end{array}$ & $\begin{array}{c}\text { Late } \\
\text { Oct., 15 }\end{array}$ \\
\hline Sept.30 & 9 & & & 5 & & \\
\hline Oct. ,7 & 11 & & & 9 & & \\
\hline Oct.,14 & 14 & 2 & & 37 & 2 & \\
\hline Oct,,21 & 23 & 5 & & 29 & 3 & \\
\hline Oct.,30 & 45 & 16 & 1 & 41 & 18 & 1 \\
\hline Nov., 6 & 172 & 28 & 4 & 72 & 37 & 3 \\
\hline Nov.,13 & 205 & 51 & 10 & 168 & 45 & 19 \\
\hline Nov.,20 & 160 & 128 & 17 & 190 & 116 & 32 \\
\hline Nov.,27 & 81 & 95 & 45 & 121 & 99 & 98 \\
\hline Dec.,4 & 110 & 82 & 102 & 95 & 85 & 67 \\
\hline Dec.,11 & 59 & 63 & 83 & 62 & 60 & 81 \\
\hline Dec.,18 & 63 & 77 & 61 & 70 & 71 & 55 \\
\hline Dec.,25 & 42 & 48 & 75 & 38 & 38 & 49 \\
\hline Jan.,1 & 31 & 56 & 40 & 27 & 29 & 28 \\
\hline Jan.,8 & & 42 & 31 & & 42 & 36 \\
\hline Jan.,15 & & 36 & 18 & & 18 & 14 \\
\hline Jan.,22 & & & 26 & & & 11 \\
\hline Jan.,29 & & & 17 & & & 5 \\
\hline Total & 1025 & 729 & 530 & 964 & 663 & 499 \\
\hline Mean & 73.2 & 52.1 & 37.9 & 68.9 & 47.4 & 35.6 \\
\hline LSD & & 33.06 & & & 23.23 & \\
\hline
\end{tabular}


These results agree with those obtained in similar studies carried out in Egypt by Ali (1993), El-Khayat et al. (1994), Baiomy (2001), Zaki et al. (2002), Mohamed (2004), Baiomy (2008) and Esmail (2013). They mentioned that the infestation by $B$. tabaci occurred on autumn cucumber under greenhouses in September then increased to reach the high level of population in November and December, then declined towards the end of cucumber growing season.

On contrary, the present results disagree with Mohamed (2011) who found that heaviest population of $B$. tabaci on squash was recorded on plants of the latest planting, while the lowest infestation occurred in the $1^{\text {st }}$ planting date. The difference between results compared to those of the present investigation may be attributed to differences in the environmental condition between locations of experiments.

\section{The cotton aphid, Aphis gossypii Glover}

As presented in Table (2) the total number of $A$. gossypii individuals counted throughout the first year (1037 aphid individuals) was higher than recorded in year 2009/ 2010 (734 individuals). It could be also noticed that highest seasonal count of aphids was associated with the latest planting date of both years (574 and 393 aphid individuals in 2008/ 2009 and 2009/2010, respectively). That was followed by infestation to plants of the common planting date (September, $30^{\text {th }}$ ) showing 368 and 266 individuals, respectively. While, the least seasonal infestation rate occurred on plants of the earliest planting date (September, $15^{\text {th }}$ ), being 95 and 75 individuals in 2008/ 2009 and 2009/2010, respectively (Table, 2).

In both years of study and with all of the three planting dates, the first two samples were completely free from any $A$. gossypii infestation. Aphids infestation started to appear in the third samples, which showed counts by few numbers of aphids that ranged from one to 5 individuals/25 cucumber leaves. Thereafter, the subsequent 4 to 6 samples showed low rates of infestation, although the aphid counts fluctuated from one week to the other. Generally, higher rates of infestation to cucumber leaves by $A$. gossypii occurred, with all of the three planting dates, during December and January. The peaks of aphids abundance occurred on December $18^{\text {th }}$ 2008 and $25^{\text {th }} 2009$ during plants growth of the $1^{\text {st }}$ planting date ( 26 and 21 individuals/ 25 leaves, respectively). These peaks were represented by 120 individuals on January, $8^{\text {th }} 2009$ and by 102 individuals on January, $15^{\text {th }} 2010$ in the common planting date, opposed to 180 and 172 A. gossypii individuals on January, $22^{\text {nd }} 2009$ and January, $29^{\text {th }} 2010$, respectively in the latest planting date (Table, 2 ).

Presented results of this study showed that the autumn cucumbers plants which were planted in the late planting date (October, $15^{\text {th }}$ ) harboured the highest 
infestation rate with $A$. gossypii, while on contrary those planted in the early planting date harbored the lowest individuals rate.

These results agree with the previous studies which were carried out by Ali (1993), Zaki et al. (2002), Saad (2002) and Baiomy (2008) who mentioned that the high population of whitefly was recorded in mid- December, and January, during autumn plantation. While, other studies of Mohamed (2004) and Esmail (2013) in Egypt recorded the highest population of $A$. gossypii on cucumber leaves in November under greenhouse conditions.

Table 2. Effect of planting dates on weakly counts of Aphis gossypiil 25 leaves autumn cucumber plants during two successive years

\begin{tabular}{|c|c|c|c|c|c|c|}
\hline \multirow{2}{*}{$\begin{array}{c}\text { Date of } \\
\text { Inspections }\end{array}$} & \multicolumn{3}{|c|}{$2008-2009$} & \multicolumn{3}{|c|}{$2009-2010$} \\
\hline & $\begin{array}{c}\text { Early } \\
\text { Sept., } 15\end{array}$ & $\begin{array}{c}\text { Normal } \\
\text { Sept, } 30\end{array}$ & $\begin{array}{c}\text { Late } \\
\text { Oct., } 15\end{array}$ & $\begin{array}{c}\text { Early } \\
\text { Sept., } 15\end{array}$ & $\begin{array}{l}\text { Normal } \\
\text { Sept, } 30 \\
\end{array}$ & $\begin{array}{c}\text { Late } \\
\text { Oct., } 15\end{array}$ \\
\hline Sept.30 & 0 & & & 0 & & \\
\hline Oct. , 7 & 0 & & & 0 & & \\
\hline Oct.,14 & 1 & 0 & & 1 & 0 & \\
\hline Oct, .21 & 1 & 0 & & 1 & 0 & \\
\hline Oct.,, 30 & 2 & 3 & 0 & 1 & 1 & 0 \\
\hline Nov., 6 & 3 & 6 & 0 & 3 & 3 & 0 \\
\hline Nov.,13 & 1 & 8 & 4 & 1 & 4 & 5 \\
\hline Nov. 20 & 1 & 4 & 2 & 5 & 11 & 1 \\
\hline Nov.,27 & 8 & 1 & 1 & 1 & 7 & 3 \\
\hline Dec., 4 & 11 & 2 & 9 & 7 & 1 & 7 \\
\hline Dec.,11 & 7 & 15 & 4 & 15 & 22 & 2 \\
\hline Dec., 18 & 26 & 37 & 35 & 6 & 19 & 27 \\
\hline Dec., 25 & 13 & 28 & 21 & 21 & 28 & 16 \\
\hline Jan.,1 & 21 & 56 & 44 & 13 & 51 & 41 \\
\hline Jan.,8 & & 120 & 38 & & 17 & 18 \\
\hline Jan.,15 & & 88 & 71 & & 102 & 34 \\
\hline Jan.,22 & & & 180 & & & 67 \\
\hline Jan.,29 & & & 165 & & & 172 \\
\hline Total & 95 & 368 & 574 & 75 & 266 & 393 \\
\hline Mean & 6.8 & 26.3 & 41 & 5.4 & 19 & 28.1 \\
\hline LSD & & NS & & & NS & \\
\hline
\end{tabular}

\section{The two spotted spider mite, Tetranychus urticae (Koch.):}

Data concerning the infestation rates by $T$. urticae on leaves of cucumber planted in three planting dates during 2008/ 2009 and 2009/ 2010 years are shown in Table (3). The recorded data showed that with all of the three planting dates, the first 4 samples were free of any red spider mites, infestation, which. started on cucumber leaves with the $5^{\text {th }}$ sample of October, $30^{\text {th }}$, November, $13^{\text {th }}$ and November, $27^{\text {th }}$ for the 
three planting dates, respectively during the two years of study. Infestation started in few numbers (1- 6/ 25 cucumber leaves). The subsequent samples showed increases in $T$. urticae counts until reached the first lower peak of population abundance showing 59 individuals on December $11^{\text {th }} 2008$ and 15 individuals in November, $27^{\text {th }} 2009$ for the early planting date. On plants of the second planting date, the $1^{\text {st }}$ peak measured 79 and 85 individuals $/ 25$ leaves December, $25^{\text {th }}$ in both years. While, plants of the $3^{\text {rd }}$ (late) planting date harboured 87 and 270 individuals on December, 25 2008 and January, $15^{\text {th }} 2010$, respectively indicating the $1^{\text {st }}$ peak of $T$. urticae population abundance. The second peak of abundance was the higher which, mostly, occurred during January. On cucumber plants of the $1^{\text {st }}$ planting date this peak was represented by 122 individuals on January, $1^{\text {st }} 2009$ and 73 individuals on December, $25^{\text {th }} 2009$. The second peak on plants of the common $\left(2^{\text {nd }}\right)$ planting date was represented by 290 and $170 T$. urticae individuals occurred on January, $15^{\text {th }}$ of both years of study. While, on plants of the $3^{\text {rd }}$ planting date, the second peak of red spider mite abundance showed the highest count which were measured by 310 individuals on January, $22^{\text {nd }} 2009$ and 320 individuals/ 25 cucumber leaves on January, $29^{\text {th }} 2010$ (Table, 3).

As shown in Table (3) the rate infestation of $T$. urticae increased as the plants grew older. Rates of infestation started low, then increased until became high during December, then reached the highest population abundance during January. It could be also, observed that highest infestation rates occurred on plants of the latest planting date (October, $15^{\text {th }}$ ), while on contrary, lowest infestation rates were recorded in both years, on plants of the earliest planting date (September, $15^{\text {th }}$ ). Plants of the common planting date (September, $30^{\text {th }}$ ) ranked as intermediately infested as the population densities of $T$. urticae were intermediate between those of the early and the late planting dates. It could be also noticed from date in Table (3) that higher seasonal infestation rates by T. urticae occurred to plants of the year 2008/ 2009 (total of 2078 individuals) that these totally counted during the subsequent year (1714 individuals, Table, 3).

Differences in the rates of infestation to cucumber plants grown from different planting dates and between the two years of study may be attributed to the variation of environmental conditions among planting dates and the two successive years.

The obtained results can be considered on line with Abd-El Gawad (2004) who reported that $T$. urticae appeared during the period from October until February. Baiomy (2008) recorded the highest infestation by the spider mites on cucumber leaves under greenhouse was found from November, $27^{\text {th }}$ to Jan., $8^{\text {th }}$. In agreement with El-khayat et al. (2010) they revealed that the numbers of different stages of $T$. urticae were increased by delaying the planting date. In other investigation, Mohamed 
(2004) found that the population of spider mites in the greenhouse were low during September, October and November, then the spider mites disappear after this period until reappeared in April, this result may be due to the differences in planting dates of crops.

Table 3. Effect of planting dates on rates of infestation by $T$. urticae/ 25 leaves of autumn cucumber plants during two successive years

\begin{tabular}{|c|c|c|c|c|c|c|}
\hline \multirow{2}{*}{$\begin{array}{c}\text { Date of } \\
\text { Inspections }\end{array}$} & \multicolumn{3}{|c|}{ 2008-2009 } & \multicolumn{3}{c|}{ 2009-2010 } \\
\cline { 2 - 7 } & $\begin{array}{c}\text { Early } \\
\text { Sept., 15 }\end{array}$ & $\begin{array}{c}\text { Common } \\
\text { Sept, 30 }\end{array}$ & $\begin{array}{c}\text { Late } \\
\text { Oct., 15 }\end{array}$ & $\begin{array}{c}\text { Early } \\
\text { Sept.,15 }\end{array}$ & $\begin{array}{c}\text { Common } \\
\text { Sept, 30 }\end{array}$ & $\begin{array}{c}\text { Late } \\
\text { Oct., 15 }\end{array}$ \\
\hline Sept.30 & 0 & & & 0 & & \\
\hline Oct. ,7 & 0 & & & 0 & & \\
\hline Oct.,14 & 0 & 0 & & 0 & 0 & \\
\hline Oct,.21 & 0 & 0 & & 0 & 0 & \\
\hline Oct.,30 & 1 & 0 & 0 & 1 & 0 & 0 \\
\hline Nov.,6 & 2 & 0 & 0 & 1 & 0 & 0 \\
\hline Nov.,13 & 4 & 1 & 0 & 3 & 1 & 0 \\
\hline Nov.,20 & 7 & 4 & 0 & 9 & 2 & 0 \\
\hline Nov.,27 & 19 & 18 & 6 & 15 & 5 & 1 \\
\hline Dec.,4 & 32 & 11 & 16 & 11 & 19 & 4 \\
\hline Dec.,11 & 59 & 46 & 43 & 27 & 22 & 23 \\
\hline Dec.,18 & 25 & 38 & 72 & 38 & 31 & 7 \\
\hline Dec.,25 & 93 & 79 & 87 & 73 & 85 & 19 \\
\hline Jan.,1 & 122 & 66 & 46 & 61 & 71 & 63 \\
\hline Jan.,8 & & 168 & 105 & & 110 & 92 \\
\hline Jan.,15 & & 290 & 111 & & 170 & 270 \\
\hline Jan.,22 & & & 310 & & & 160 \\
\hline Jan.,29 & & & 197 & & & 320 \\
\hline Total & 364 & 721 & 993 & 239 & 516 & 959 \\
\hline Mean & 26 & 51.5 & 70.9 & 17.1 & 36.9 & 68.9 \\
\hline LSD & & NS & & & NS & \\
\hline
\end{tabular}

\section{Efficacy of untraditional acaricides against the two spotted spider mite,}

\section{Tetranychus urticae (Koch) on cucumber plants under greenhouse:}

This experiment was designed to evaluate the efficacy of nine acaricides (chemical and biological) against $T$. urticae infesting cucumber plants in the greenhouse in spring season at Giza governorate. 


\section{A. Reduction after $\mathbf{2 4}$ hours (Initial Kill):}

Data in Table (4\&5) cleared that the reduction percentages of nine treatments were ranged between $96.33 \%$ resulted $24 /$ hours after Agromec $1.8 \%$ EC treated and $57.61 \%$ obtained after Bio-Fly $\left(3 \times 10^{6}\right.$ unit $)$ treatment.

Chemical acaricide gave over $80 \%$ reduction were: Pyricide $24 \%$ EC gave $94.81 \%$, Citroguard $15 \%$ EC gave $93.18 \%$ reduction, while bio-acaricides gave over $70 \%$ reduction were: Agromec 1.8\% EC gave 96.33\% Perv- AM 6\% SL gave 88.58\%, Biolarve 5\% EC (rate 15 CC) gave $85 \%$, Bio larve 5\% EC (rate 30 CC) gave $81.89 \%$.

\section{B. Mean of the reduction after 7 days (residual effect):}

Table (5) indicated that the average of the reduction of mobile skeges of spider mites related with chemical compounds gave over $80 \%$ reduction were Pyricide 24\% EC (94.98\%), Acari-stope 50\% SC (93.7\%) and Citroguard15\% EC (81.9\%), while the bio- acaricides gave over 70\% reduction were: Agromec $1.8 \%$ EC (93.69\%), Bio-larve 5\% EC (30 cC) 89.31\%), prev-AM 6\% SL (87.84), Milbeknock 1\% EC $(81.11 \%)$ Bio-larva (15 cc) $(79.3 \%)$ and Bio-fly $\left(3 \times 10^{6}\right.$ units) $(74.4 \%)$ reduction .

Generally, it could be recommended that the chemical and bio- acaricides could be used to control $T$. urticae on cucumber plants. The tested compounds gave result of initial kill (after 24 hours) except Acari-stop (chemical acaricide) and Bio-fly (bio- acaricide) gave low reduction of T. urticae in different group levels.

On the other hand, on changes of reduction of residual effect between different groups of acaricides after 7 days and there are could be using any compounds which were considered selectivity, safety and effective to give best control against the two spotted spider mites on cucumber plants under protected cultivation.

These results agree with, Szwejda (1994) who reported that abamectin gave excellent control of spider mites on cucumber under greenhouse in Poland and caused more than 98\% mortality. Nakamura and Sasak (2004) tested twelve acaricides and found that the milbemectin achieved good control (100\% mortality $48 \mathrm{~h}$ after spray) on both females and eggs of $T$. urticae,Peric et al (2009) found that the efficacy of abamectin against T. urticae on cucumber was 92.2\%. Abdel-Wali et al. (2012) found the mortality of abamectin, milbemectin and chlorafenapyr on the two spotted spider mites under plastic greenhouses was $92.9 \%$ after one day of application. Dutta et al. (2012) recorded that the abamectin provided high reduction of mite population (83.4\%). Seyed et al. (2012) mentioned that the fungus Beauveria bassiana was effected on the larval stage of $T$. urticae. 
Table 4. Efficacy of some Acaricides against two spotted spider mites on cucumber plants under plastic greenhouse at protected cultivation center on summer seasons 2012.

\begin{tabular}{|c|c|c|c|c|c|c|c|c|c|c|c|c|c|c|c|c|}
\hline \multirow{3}{*}{ Acaricides } & \multirow{3}{*}{$\begin{array}{l}\text { Rate per } \\
100 \mathrm{~L} \text { water }\end{array}$} & \multirow{3}{*}{$\begin{array}{l}\text { No. mobile } \\
\text { individuals } \\
\text { pre. spray }\end{array}$} & \multirow{2}{*}{\multicolumn{2}{|c|}{$\begin{array}{c}\text { initial kill } \\
24 \mathrm{hr} .\end{array}$}} & \multicolumn{12}{|c|}{ Residual Effect } \\
\hline & & & & & \multicolumn{2}{|c|}{3 days } & \multicolumn{2}{|c|}{5 days } & \multicolumn{2}{|c|}{7 days } & \multicolumn{2}{|c|}{10 days } & \multicolumn{2}{|c|}{12 days } & \multicolumn{2}{|c|}{15 days } \\
\hline & & & No. & $\%$ & No. & $\%$ & No. & $\%$ & No. & $\%$ & No. & $\%$ & No. & $\%$ & No. & $\%$ \\
\hline $\begin{array}{c}\text { Acari-stop } \\
50 \% \mathrm{SC}\end{array}$ & $40 \mathrm{CC}$ & 703 & 689 & 59.54 & 153 & 92.42 & 127 & 92.58 & 83 & 95.93 & 98 & 96.15 & 36 & 97.99 & 5 & 99.70 \\
\hline $\begin{array}{c}\text { Milbeknock 1\% } \\
\text { EC }\end{array}$ & $50 \mathrm{CC}$ & 514 & 340 & 72.69 & 388 & 73.71 & 255 & 79.61 & 154 & 89.67 & 160 & 91.40 & 65 & 95.05 & 54 & 95.64 \\
\hline Prev. AM 6\% SL & $400 \mathrm{CC}$ & 347 & 96 & 88.58 & 121 & 87.86 & 111 & 86.82 & 114 & 88.68 & 129 & 89.73 & 62 & 93.00 & 31 & 96.29 \\
\hline Bio- larve $5 \%$ EC & $30 \mathrm{CC}$ & 317 & 93 & 81.89 & 72 & 92.09 & 106 & 86.26 & 100 & 89.13 & 110 & 90.41 & 74 & 90.86 & 59 & 92.28 \\
\hline $\begin{array}{c}\text { Bio-fly } \\
\left(3 \times 10^{6} \text { units }\right)\end{array}$ & $50 \mathrm{CC}$ & 337 & 346 & 57.61 & 316 & 67.35 & 248 & 69.76 & 144 & 85.27 & 166 & 86.39 & 78 & 90.94 & 67 & 91.75 \\
\hline $\begin{array}{c}\text { Agromec } 1.8 \% \\
\text { EC }\end{array}$ & $50 \mathrm{CC}$ & 562 & 50 & 96.33 & 81 & 94.98 & 108 & 92.10 & 102 & 93.74 & 121 & 94.05 & 90 & 93.73 & 98 & 92.76 \\
\hline Bio- larve $5 \%$ EC & $15 \mathrm{CC}$ & 552 & 194 & 85.49 & 295 & 81.39 & 308 & 77.07 & 333 & 79.21 & 338 & 83.08 & 148 & 89.50 & 164 & 87.67 \\
\hline Pyricide $24 \%$ EC & $75 \mathrm{CC}$ & 374 & 47 & 94.81 & 62 & 94.23 & 52 & 94.29 & 40 & 96.31 & 90 & 93.35 & 59 & 93.82 & 51 & 94.34 \\
\hline $\begin{array}{c}\text { Citroguard } 15 \% \\
\text { EC }\end{array}$ & 200 CC & 351 & 58 & 93.18 & 158 & 84.33 & 179 & 79.04 & 184 & 81.93 & 216 & 83.00 & 114 & 87.28 & 105 & 87.58 \\
\hline Control & $\begin{array}{c}\text { Without } \\
\text { Treatment }\end{array}$ & 547 & 1325 & - & 1571 & - & 1331 & - & 1587 & - & 1980 & - & 1397 & - & 1318 & - \\
\hline
\end{tabular}


Table 5. Reduction percentages of $T$. urticae population after treatments with some acaricides on cucumber plants under greenhouse during 2012.

\begin{tabular}{|c|c|c|c|c|c|c|}
\hline \multirow{2}{*}{ Acaricides } & \multirow{2}{*}{$\begin{array}{c}\text { Rate / 100 L } \\
\text { water }\end{array}$} & $\begin{array}{c}\text { No. mobile } \\
\text { individuals pre. } \\
\text { Spray }\end{array}$ & No. & $\%$ & initial kill (24 hr) & \multicolumn{2}{c|}{ Residual Effect (7days) } \\
\cline { 5 - 7 } & $40 \mathrm{CC}$ & 703 & 689 & 59.54 & 363 & 93.7 \\
\hline Acari-stop 50\%SC & $50 \mathrm{CC}$ & 514 & 340 & 72.69 & 797 & 81.11 \\
\hline Milbeknock 1\% EC & $300 \mathrm{CC}$ & 347 & 96 & 88.58 & 346 & 87.84 \\
\hline Prev. AM 6\% SL & $30 \mathrm{CC}$ & 317 & 93 & 81.89 & 278 & 89.31 \\
\hline Bio- larve 5\% EC & $50 \mathrm{CC}$ & 337 & 346 & 57.61 & 708 & 74.4 \\
\hline $\begin{array}{c}\text { Bio- fly } \\
\left(3 \times 10^{6} \text { units }\right)\end{array}$ & $50 \mathrm{CC}$ & 562 & 50 & 96.33 & 291 & 93.69 \\
\hline Agromec 1.8\% EC & $15 \mathrm{CC}$ & 552 & 194 & 85.49 & 936 & 79.3 \\
\hline Bio-larve 5\% EC & $75 \mathrm{CC}$ & 374 & 47 & 94.81 & 154 & 94.98 \\
\hline Pyricide 24\% EC & $200 \mathrm{CC}$ & 351 & 58 & 93.18 & 521 & 81.9 \\
\hline $\begin{array}{c}\text { Citroguard 15\% } \\
\text { EC }\end{array}$ & Without & 547 & 1325 & - & 4489 & - \\
\hline Control & Treatment & & & & & \\
\hline
\end{tabular}

\section{REFERENCES}

1. Abd El-Gawad, A. Samia. 2004. Biological, Ecological and biocontrol studies on some mites. M.Sc. Thesis, Fac. of Sci. (girls) of Al-Azhar Univ., 168 Pp.

2. Abdel-Wahed, N. M. 2003. "Studies on some mites associated with certain fruit trees." Ph.D. Thesis, Fac. of Agric., Al-Azhar Univ., Pp. 188.

3. Abdel-Wali, M., T. Mustafa and M. Al-Lala. 2012. Residual toxicity of abamectin, milbemectin and chlorfenapyr to different populations of two spotted spider mite, Tetranychus urticae Koch, (Acari: Tetranychidae) on cucumber in Jordan. World Journal of Agri. 8:2,147- 178.

4. Ali, F. A. 1993. Integrated pest management of some sucking insects attacking cucumber plants under protected cultivation in Egypt. J. Agric. Sci. Mansoura Univ., 18(6): 1867-1877.

5. Baiomy, Fatina, A. M. 2001. Ecological studies on some pests of protected cultivation at northern Africa. MSc.Thesis, Ins. African Res. Studies, Cairo Univ $136 \mathrm{Pp}$.

6. Baiomy, Fatina, A. M. 2008. Efficiency of modern methods for controlling some vegetable pests in greenhouses in Egypt and Morocco.PhD .Thesis, Ins. African Res. Studies, Cairo Univ. 154pp.

7. Dutta, N. K., S. N. Alam, M. K. Uddin, , M. Mahmudunnabi and M.F. Khatun. 2012. Population abundance of red spider mite in different vegetables along with its spatial distribution and chemical control in brinjal (Solanum melongena L.). Bangladesh Journal of Agricultural Research,. 37: 3, 399-404. 11 ref. 
8. El-Khayat, E. F., El-Syed, A. M., Shalaby, F. F. and Hady, S.A. (1994). Infestation rates with Bemisia tabaci (Genn) to different summer and winter vegetable crop plants. Annals of Agricultural Science Moshtohor, 32 (1), 577-594.

9. El-Khayat, E.F., El-Lakwah, F.A., Rady, G.H.H., Mona, M.A. Ghallab and B.S. Wahba. 2010. "Impact of planting dates on infestation of cowpea plants with some pests, Egyp. J. Agric. Res., 88 (4): 1107-1120.

10. Esmail, S.S.G. 2013. "Performance of some control elements for sap-sucking insect pests under protected cultivation. M.Sc. Thesis, Fca. Of Agri., Ain Shams Univ $130 \mathrm{Pp}$.

11. Henderson, C.F. and E.W. Tilton. 1955. "Test with acaricides against the brown wheat mite. " J. Econ. Ent., 48: 157- 161.

12. Mohamed, Amna, O. H. 2004. Ecological studies on some insect and animal pests infesting certain vegetable crops under protected cultivation and their control. M.Sc. thesis, Fac. of Afric, Al-Azhar Univ.321pp.

13. Mohamed, Mona A. 2011. Effect of planting dates on infestation with certain pests and yield parameters of squash plants." Egyp. J. Agric. Res., 89 (4): 13531362.

14. Nakamura, A. and M. Sasaki. 2004. Effects of acaricides on two-spotted spider mite, Tetranychus urticae Koch, collected from cucumber in Fuku. [Japanese]Annual Report of the Society of Plant Protection of North Japan, 55, 207-210. 4 ref.

15. Peric, P., D. Marcic, M. Prijovic , I. Ogurlic and G. Andric. 2009. Effectiveness of biorational pesticides for controlling some vegetable pests in Serbia. Acta Horticulturae,. 830, 531-538. 16 ref.

16. Saad, H.M. 2002. Economics of the integrated pest management of certain insect and animal pests on most important vegetable crops production under plastic greenhouse. M.Sc, Thesis, Fac. of Agri., Moshtohor, Zeg. Univ., Benha Branch $203 \mathrm{Pp}$.

17. Seyed-Talebi, F. S., K. Kheradmand, R. Talaei-Hassanloui and K. Talebi-Jahromi. 2012. Sublethal effects of Beauveria bassiana on life table parameters of twospotted spider mite, Tetranychus urticae (Acari: Tetranychidae). Biocontrol Science and Technology,. 22: 3, 293-303.

18. Szwejda, J. 1994. Evaluation of the effectiveness of some acaricides in the control of the red spider mite (Tetranychus urticae koch.) on tomatoes and cucumbers in greenhouses. [Polish]Biuletyn Warzywniczy, 41: 101-108. 7 ref.

19. Zaki, F.N., M.F. El-Shaarawy and N.A. Farag. 2002. Population of aphids, whiteflies and associated predators and parasites on different vegetables cultivated in plastic greenhouses. J. Pest Science, 75: 128-131. 


\section{موعد الزراعة وعلاقته بالآفات الحشرية والحيوانية التى تصيب نباتات الخيار تحت الزراعات المحمية فى محافظة الجيزة}

فوزى فائق شلبى' ، فتحى عبد العزيز على'، عادل عبد الحميد حافظ '، هيام مصطفى سعد r

$$
\begin{aligned}
& \text { ا - قسم وقاية النباتات - كلية النزراعة - جامعة بنها } \\
& \text { r - معز بحوث وقاية النباتات - مركز البحوث الزراعية - الدقى - الجيزة. }
\end{aligned}
$$

تزرع نباتات الخيار فى الصوب الزراعية فى الموسم الخريفى والربيعى من كل عام. ويعتبر الموسم الخريفى هو الأهم فى إمداد الأسواق بثمار الخيار فى أوقات الجو البارد. واعثى والأفات

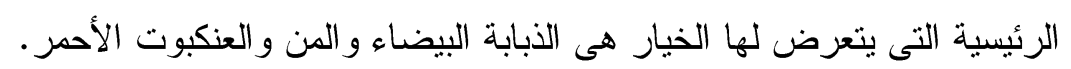

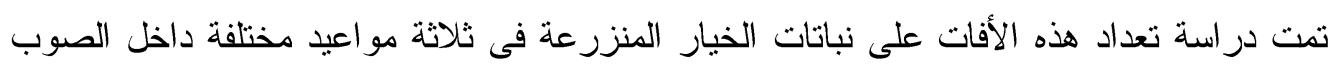

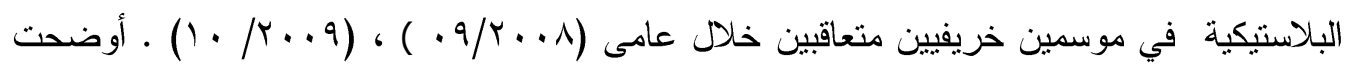

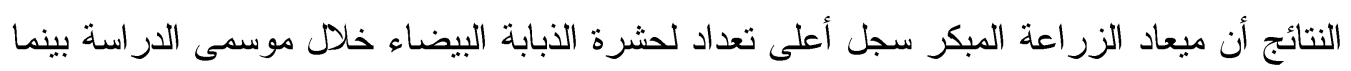

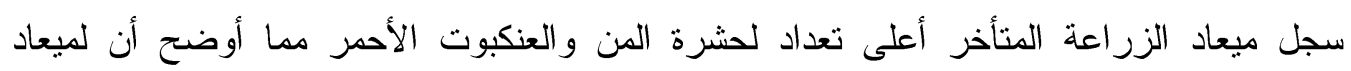

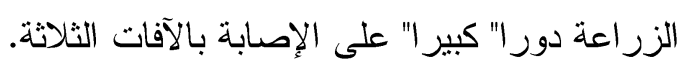

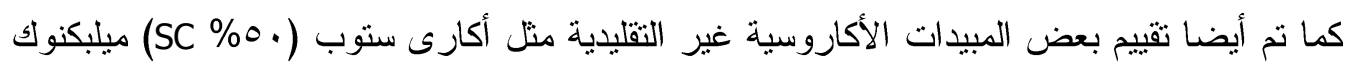

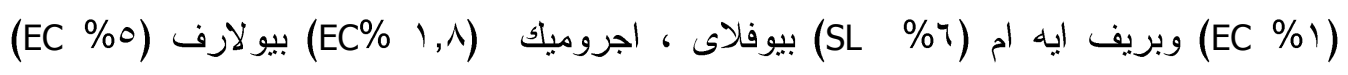
بيريسايد (

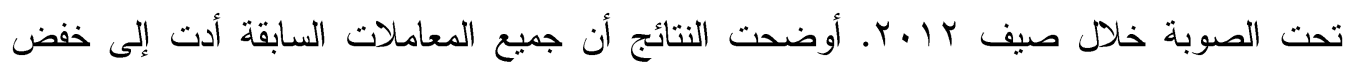

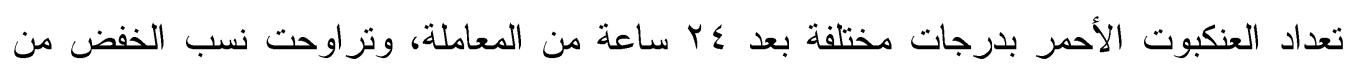

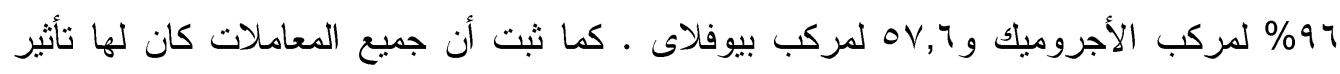
فعال فى خفض تعداد الأفة بعد V أيام من الرش مما أثبت أنه من الممكن استخدام أى مبيد منها بأمان. 